\title{
Management of Severe Curly Top in Sugar Beet with Insecticides
}

Carl A. Strausbaugh, United States Department of Agriculture-Agricultural Research Service (USDA-ARS) NWISRL, Kimberly, ID 83341-5076; Erik J. Wenninger, University of Idaho, Kimberly 83341; and Imad A. Eujayl, USDA-ARS NWISRL

\begin{abstract}
Strausbaugh, C. A., Wenninger, E. J., and Eujayl, I. A. 2012. Management of severe curly top in sugar beet with insecticides. Plant Dis. 96:11591164.

Curly top, caused by Curtovirus spp., is a widespread disease problem vectored by the beet leafhopper in semiarid sugar beet production areas. The insecticide seed treatment Poncho Beta has proven to be effective in controlling curly top in sugar beet but was only evaluated under light to moderate disease pressure. Thus, the insecticide seed treatments Poncho Beta, NipsIt INSIDE, and Cruiser Force were evaluated under severe curly top pressure (six viruliferous beet leafhoppers per plant) in field studies during the 2010 and 2011 growing seasons on two commercial sugar beet cultivars. In addition, the foliar insecticides Movento, Provado, and Scorpion were also evaluated. The seed treat-

ments and Scorpion reduced curly top symptoms by 33 to $41 \%$ ( $P<$ $0.0001)$ and increased root yield by 55 to $95 \%(P<0.0001)$, sucrose content by 6.5 to $7.2 \%(P=0.0013$ to $<0.0001)$, and estimated recoverable sucrose by 58 to $96 \%(P<0.0001)$ when compared with the untreated check. Movento and Provado did not improve control beyond that provided by Poncho Beta. Even under severe disease pressure 50 to 55 days after planting, neonicotinoid seed treatments can effectively reduce curly top, increase yield, and help protect against early-season insect pest pressure.
\end{abstract}

Curly top in sugar beet semiarid production areas of the United States is caused by one of three Curtovirus spp. (29,35): Beet severe curly top virus (BSCTV), Beet mild curly top virus (BMCTV), and Beet curly top virus (BCTV). However, the number of Curtovirus spp. or proposed species has increased in recent years and some have been shown to occur on sugar beet in other countries $(5,7,14,15,19,39)$. Finding more than one of the Curtovirus spp. (BCTV, BMCTV, and BSCTV) in a sugar beet plant is not uncommon (35). The virus species that cause curly top are vectored by the beet leafhopper, Circulifer tenellus Baker (Hemiptera: Cicadellidae) (3). Adult female beet leafhoppers overwinter on sagebrush steppe vegetation and weeds in desert areas and poorly managed residential areas near sugar beet fields $(3,4)$. Overwintered females lay eggs in the spring, leading to the start of approximately three generations under Idaho conditions (3). In warmer semiarid production areas of the United States, additional beet leafhopper generations may occur. When winter host plants desiccate in the spring, the beet leafhoppers move into crop areas carrying the curly top viruses $(3,4,8)$. Although the beet leafhopper is polyphagous and has many hosts, sugar beet is a preferred host $(3,16)$. If the beet leafhopper migrates early in the season and a sugar beet plant is infected at an early growth stage, curly top damage is worse than if infection occurs at later growth stages $(10,26,38)$.

Sugar beet cultivars with resistance to curly top became commercially available in the mid-1930s, prior to which curly top al-

Corresponding author: C. A. Strausbaugh,

E-mail: carl.strausbaugh@ars.usda.gov

* The e-Xtra logo stands for "electronic extra" and indicates that a supplementary figure is available online.

Mention of trade names or commercial products in this article is solely for the purpose of providing specific information and does not imply recommendation or endorsement by the United States Department of Agriculture.

Accepted for publication 29 February 2012.

http://dx.doi.org/10.1094/PDIS-01-12-0106-RE

This article is in the public domain and not copyrightable. It may be freely reprinted with customary crediting of the source. The American Phytopathological Society, 2012. most eliminated the sugar beet industry in the western United States $(3,4)$. However, resistance in sugar beet cultivars tends to be low to intermediate (31). Resistance to curly top in sugar beet is thought to be multigenic and, therefore, difficult to maintain in the parental lines used to create the commercial hybrids $(12,18)$. When new traits are rapidly incorporated into sugar beet, such as the $R z l$ gene for rhizomania resistance, it takes the seed companies many years to get curly top resistance back up to the same levels that were present prior to the change $(6,31)$. As mentioned previously, those prior resistance levels in commercial cultivars were often only marginally acceptable. Another drawback to relying on host resistance is the tendency for lower yield potential to occur while maintaining the curly top resistance (12). Thus, alternative control measures are needed to alleviate curly top losses.

In Idaho during the 1960s, beet leafhopper populations in the desert areas were monitored and sprayed with insecticides (4). However, it was determined that beet leafhopper counts in the desert areas did not accurately reflect future movement into sugar beet production areas, and the financial and environmental costs of spraying the desert areas were no longer justifiable by 1970 (4). Thus, in-furrow, foliar, and seed-treatment insecticides have been considered for controlling curly top in sugar beet $(18,21,23,32,37)$. The seed treatment based on the neonicotinoid insecticide clothianidin (marketed as Poncho Beta) was established as an effective management tool to supplement host resistance (32). Initial research showed that the seed treatment had the potential to increase yields approximately $20 \%$ in sugar beet with low to moderate curly top pressure (32). In Idaho during the first 5 years (2006 to 2010) with Poncho Beta available, yields have averaged $72.92 \pm 3.79 \mathrm{t} / \mathrm{ha}$ whereas, during the preceding 5 years (2001 to 2005), yields only averaged $60.62 \pm 4.51 \mathrm{t} / \mathrm{ha}$ (9). The annual usage rate of Poncho Beta is unknown and other factors such as glyphosate-resistant cultivars (first available in 2008) may have contributed to some of this yield increase. Similar yield responses have also been noted in other semiarid western production areas, in which some sugar cooperatives have required clothianidin to be applied to all sugar beet seed. However, initial testing only evaluated clothianidin as a seed treatment under low to moderate natural pressure (32). The efficacy of the seed treatment was not evaluated under severe curly top pressure, and the length of efficacy was not established. Also, additional seed treatment and foliar insecticide products are now available. Thus, studies were conducted to establish the efficacy of neonicotinoid seed treatments under severe (six viruliferous beet 
leafhoppers per plant) curly top pressure, clarify the length of efficacy, and compare the efficacy of foliar insecticide treatments with the neonicotinoid seed treatments.

\section{Materials and Methods}

Treatments. In total, 12 treatments (an untreated check plus 5 insecticide treatments on two sugar beet cultivars) were evaluated for their ability to control severe curly top. In addition to the untreated check, the insecticide treatments included three seed treatments: Poncho Beta (Bayer CropScience, RTP, NC), with clothianidin at $60 \mathrm{~g}$ a.i. $+\beta$-cyfluthrin at $8 \mathrm{~g}$ a.i. per 100,000 seeds; Cruiser Force (Syngenta Crop Protection, Greensboro, NC), with thiamethoxam at $60 \mathrm{~g}$ a.i. + tefluthrin at $8 \mathrm{~g}$ a.i. per 100,000 seeds; and NipsIt INSIDE (Valent U.S.A. Corp., Walnut Creek, CA), with clothianidin at $60 \mathrm{~g}$ a.i. per 100,000 seeds. A fifth treatment evaluated the Poncho Beta-treated seed along with two foliar insecticides applied together: Movento 240 SC (Bayer CropScience), with spirotetramat at $88 \mathrm{~g}$ a.i./ha and Provado 1.6F (Bayer CropScience), with imidacloprid at $52.8 \mathrm{~g}$ a.i./ha. A sixth treatment which was evaluated only in 2011 included no insecticide seed treatment and only the foliar insecticide Scorpion 35SL (Gowen Company LLC, Yuma, AZ), with dinotefuran at $149 \mathrm{~g}$ a.i./ha. During 2010, foliar sprays were applied on 15 June ( 8 days prior to beet leafhopper release) and repeated on 28 June ( 5 days after release). Foliar sprays were applied using a $\mathrm{CO}_{2}$-powered backpack sprayer at $2.1 \mathrm{~kg} / \mathrm{cm}^{2}$, using a boom with a $8002 \mathrm{VS}$ spray nozzle (TeeJet Technologies, Wheaton, IL) centered over each of the four rows of the plot. The sprayer was calibrated to release a volume of 168 liters/ha. These six treatments were each evaluated on two conventional (do not contain glyphosate resistance) sugar beet cultivars ('B-45' and ' $\mathrm{C}-21$ '; for more information on coded cultivar names, contact Betaseed Inc. and ACH Seeds, respectively) that contain low levels of curly top resistance (31). Prior to application of the seed treatments, a minimum seed treatment build-up (a claybark material was used to increase seed weight by 30\%) was applied to the seed by Aztec Seed Technology, Sheridan, WY. The three insecticide seed treatments were then applied to the seed as follows: Poncho Beta (applied by Bayer CropScience), Cruiser Force (applied by Syngenta Crop Protection, Stanton, MN), and NipsIt INSIDE (applied by Valent U.S.A. Corp., Leland, MS). To limit the influence of fungal pathogens and allow for good stand establishment, each company also applied fungicides that will probably accompany the insecticides when sold commercially. Poncho Beta-treated seed and the non-insecticide-treated check received Allegiance FL (metalaxyl at $15.6 \mathrm{~g}$ a.i. per $100 \mathrm{~kg}$ of seed) and Thiram 42S (thiram at $250 \mathrm{~g}$ a.i. per $100 \mathrm{~kg}$ of seed). Cruiser Force-treated seed received Apron XL (mefenoxam at $7.5 \mathrm{~g}$ a.i. per $100 \mathrm{~kg}$ of seed) and Maxim 4FS (fludioxonil at $2.5 \mathrm{~g}$ a.i. per 100 $\mathrm{kg}$ of seed). NipsIt INSIDE-treated seed received Allegiance FL (metalaxyl at $15.6 \mathrm{~g}$ a.i. per $100 \mathrm{~kg}$ of seed) plus Metlock (metconazole at $20 \mathrm{~g}$ a.i. per $100 \mathrm{~kg}$ of seed).

Field plots, 2010. The 2010 field plots were located in Twin Falls County on the United States Department of Agriculture-Agricultural Research Service North Farm $\left(42^{\circ} 33.177^{\prime}\right.$ N, $114^{\circ} 21.350^{\prime}$
W) near Kimberly, ID. The 12 treatments were arranged in a randomized complete block design with eight replications. The preceding crop in 2009 was dry bean, and the field was disked on 16 March 2010. Fertilizer ( $\mathrm{N}$ at $33.6 \mathrm{~kg} / \mathrm{ha}$ and $\mathrm{P}_{2} \mathrm{O}_{5}$ at 179.3 $\mathrm{kg} / \mathrm{ha}$ ) and the herbicide ethotron (42\% ethofumesate) at $2.33 \mathrm{li}-$ ters/ha were applied on 7 April and incorporated with a roller harrow. The trial was planted on 3 May to a density of 352,272 seeds/ha. The trial was thinned to a density of 117,424 plants/ha on 12 June. Plots were four rows wide (56-cm row spacing) and 10.4 $\mathrm{m}$ long. The field was managed using standard cultural practices. Irrigation water was applied through handlines as needed to replace evapotranspiration based on data from the Twin Falls AgriMet station (1.08 km from plots). Prior to thinning, a stand count was taken on 20 May, when the plants had only cotyledons and no true leaves. On 22 June (50 days after planting) at the six- to eight-leaf growth stage, the percentage of plants with damage from the beet leafminer, Pegomya betae Curtis (Diptera: Anthomyiidae), in the center two rows was recorded. No curly top or only trace levels of natural curly top pressure were evident in this production area; therefore, six viruliferous beet leafhoppers per plant were released on 23 June (51 days after planting) to create a severe uniform curly top epiphytotic. The viruliferous beet leafhoppers came from the Beet Sugar Development Foundation insectory maintained in Twin Falls, ID. Plants in the center two rows were given a curly top rating using a disease index (22) of 0 to 9 (Table 1) in a continuous manner on 16 July, 16 August, and 16 September. After the July rating, six symptomatic plants were arbitrarily selected to determine the Curtovirus spp. present in the plants. Other disease problems were not evident in the field during the growing season. The center two rows were mechanically topped on 6 October and harvested with a small plot harvester. During harvest, two eight-beet samples per plot were collected for sugar analysis (see "Sugar analysis and yield," below).

Field plots, 2011. In 2011, the 2010 experiment was repeated using field plots located in an adjacent field $\left(42^{\circ} 33.246^{\prime} \mathrm{N}\right.$, $114^{\circ} 21.242^{\prime} \mathrm{W}$ ) on the same farm. The trial was conducted the same way, except for some minor changes. The previous crop was barley, and the field was disked and plowed in fall 2010. Fertilizer ( $\mathrm{N}$ at $89.7 \mathrm{~kg} / \mathrm{ha}$ and $\mathrm{P}_{2} \mathrm{O}_{5}$ at $134.5 \mathrm{~kg} / \mathrm{ha}$ ) and ethotron were applied on 20 April and incorporated with a roller harrow. The trial was planted on the same day and at the same density as in 2010 . On 14 June, the trial was thinned to a density as in 2010. Prior to thinning, a stand count was taken on 25 May, when the plants had only cotyledons and no true leaves. On 20 June (48 days after planting) at the six- to eight-leaf growth stage, the percentage of plants with leafminer damage in the center two rows was recorded. No curly top or only trace levels of natural curly top pressure were evident in surrounding production areas; therefore, six viruliferous beet leafhoppers per plant were released on 27 June ( 55 days after planting) to create a severe uniform curly top epiphytotic. The foliar insecticides were applied on 21 June, 6 days prior to beet leafhopper release, and again 8 days after release. Other than curly top, powdery mildew was the only disease problem evident in the field during the growing season. However, the powdery mildew

Table 1. Beet curly top disease rating system utilized by the Beet Sugar Development Foundation

\begin{tabular}{ll}
\hline Rating & \multicolumn{1}{c}{ Description of plant symptoms $\mathbf{z}^{\mathbf{z}}$} \\
\hline 0 & Healthy; no symptoms \\
1 & Vein clearing of heart leaves, slight pimpling of veins on the underside of leaves \\
2 & Slight leaf curl of the edges of new leaves; pimpling on the veins of the underside of the leaves \\
3 & Center few whorls of leaves with curling edges \\
4 & Most leaves moderately curling; more than half of the upper surface of the leaf visible \\
5 & Slight stunting, severe leaf curling; less than half of the upper leaf surface visible due to curling; most of the larger leaves still erect \\
6 & Stunting, slight yellowing; most leaves becoming prostrate \\
7 & Severe stunting, yellowing; leaves prostrate and some leaves dead \\
8 & Only the center few whorls of leaves green and alive \\
9 & Plant dead
\end{tabular}

${ }^{\mathrm{z}}$ Rating system was published by David Mumford in 1974 (22). The rating system was utilized in a continuous manner rather than categorically. Thus, any number, including decimal numbers, between 0 and 9 were possible when scoring the plants. 
came in late in the season (September) and should not have adversely affected yield. Curly top in the center two rows was rated on 19 July, 16 August, and 19 September. The center two rows were harvested on 4 October.

Curtovirus spp. evaluation. In both 2010 and 2011, six plants in the trials were randomly sampled after the July rating to determine the species present in the trial. DNA extraction and polymerase chain reaction (PCR) were conducted as described previously (35) and a brief overview is given in this section. The leaf tissue was sampled by punching out a disk with the cap of a sterile 2-ml microcentrifuge tube from each of four leaves per sample, and stored at $-80^{\circ} \mathrm{C}$. The DNA was extracted using a DNeasy Plant Mini Isolation kit (Qiagen Inc., Valencia, CA) and stored at $-20^{\circ} \mathrm{C}$. PCRs were performed in volumes of $25 \mu \mathrm{l}$ with the components in the master mix at the following concentrations: $1 \times$ PCR buffer (GeneAmp 10× PCR Gold buffer with $150 \mathrm{mM}$ Tris-HCl, $\mathrm{pH}$ 8.0, and $500 \mathrm{mM} \mathrm{KCl}$; Applied Biosystems, Foster City, CA), $2.5 \mathrm{mM}$ $\mathrm{MgCl}_{2}$ (Applied Biosystems), $200 \mu \mathrm{M}$ dNTPs (Applied Biosystems), $0.2 \mu \mathrm{M}$ primers, 0.65 units of AmpliTaq Gold (Applied Biosystems), and $60 \mathrm{ng}$ of DNA. Amplification consisted of $5 \mathrm{~min}$ at $95^{\circ} \mathrm{C}$ followed by 34 cycles of $95^{\circ} \mathrm{C}$ for $1 \mathrm{~min}, 54^{\circ} \mathrm{C}$ for $1 \mathrm{~min}$, and $72^{\circ} \mathrm{C}$ for $1 \mathrm{~min}$. After the last cycle, the reaction was held at $72^{\circ} \mathrm{C}$ for $5 \mathrm{~min}$ and then $4^{\circ} \mathrm{C}$. Samples were tested for the presence of Curtovirus spp. by PCR amplification of the replication-associated protein (rep) gene using the following species-specific primers (35): BSCTV-C1 2315F 5'-CGGAATCCAAACCAAAATAAG AATC- $3^{\prime}$ and BSCTV-C1 2740R 5'-AAGTCCAGATTCGTAATG CCCGT-3', region amplified matches a 426-bp segment from GenBank accession U02311 (BSCTV-CFH complete genome); BMCTV-C1 2213F 5'-GGCATCCACCCCGAAATAAGAATC-3' and BMCTV-C1 2609R 5'-CGACATCACTCATCCTTCCTC AAGC-3', region amplified matches a 397-bp segment from GenBank accession AY134867 (BMCTV-Worland4 complete genome); and BCTV-C1 2097F 5'-TGCTCCAATAAGGTGCTT CCAGTG-3' and BCTV-C1 2387R 5'-TTTCCTCTGTCCTCA TTCACAAACG-3', region amplified matches a 291-bp segment from GenBank accession AF379637 (BCTV-Cal/Logan complete genome). Amplification products were electrophoresed through agarose gels $(2 \% \mathrm{wt} / \mathrm{vol})$ supplemented with ethidium bromide $(0.002 \mathrm{mg} / \mathrm{ml})$ in Tris-borate-EDTA buffer $(89 \mathrm{mM}$ Tris base, $89 \mathrm{mM}$ boric acid, and $2 \mathrm{mM}$ EDTA). DNA from CTS07-11ID (contains BCTV, BMCTV, and BSCTV) served as a positive control (35). Reactions without template DNA served as negative controls.

Sugar analysis and yield. Two eight-beet samples collected from each plot at harvest were submitted to the Amalgamated Sugar Company Tare Lab in Paul, ID. Percent sucrose was determined using an Autopol 880 polarimeter (Rudolph Research Analytical, Hackettstown, NJ) and a half-normal weight sample dilution and aluminum sulfate clarification method (ICUMSA Method GS6-3 1994) (2). Conductivity was measured using a Foxboro conductivity meter Model 871EC (Foxboro, Foxboro, MA) and nitrate was measured using a multimeter Model 250 (Denver Instruments, Denver, CO) with Orion probes 900200 and 9300 BNWP (Krackler Scientific, Inc., Albany, NY). Estimated recoverable sucrose yield per ton of roots was calculated using the following equation: [(extraction $) \times(0.01) \times($ gross sucrose $/$ ha $)] /$ $(\mathrm{t} / \mathrm{ha})$, where extraction $=250+[[(1255.2) \times($ conductivity $)-$ $(15000) \times($ percent sucrose -6185$)] /[($ percent sucrose $) \times(98.66-$ $[(7.845) \times($ conductivity $)])]]$ and gross sucrose $=[[(\mathrm{t} / \mathrm{ha}) \times($ percent sucrose $)] \times(0.01)] \times(1,000 \mathrm{~kg} / \mathrm{t})$. The mean of the two samples from each plot were used for analyses.

Data analysis. The SAS Univariate procedure (SAS version 9.2; SAS Institute Inc., Cary, NC) was used to test for normality. These data were subjected to analysis of variance using the SAS generalized linear models procedure (Proc GLM). Fisher's protected least significant difference was used for mean comparisons following significant treatment effects $(\alpha=0.05)$.

\section{Results}

Stand. In 2010, there were no significant $(P=0.7732$ for B-45 and $P=0.7331$ for $\mathrm{C}-21)$ differences in stand among treatments with either cultivar (Table 2). In 2011, there were no stand differ-

Table 2. Influence of insecticide seed and foliar treatments on stand and leafminer using two conventional commercial sugar beet cultivars ('B-45' and 'C$21^{\prime}$ ) during the 2010 and 2011 growing seasons near Kimberly, ID ${ }^{\mathrm{w}}$

\begin{tabular}{|c|c|c|c|c|c|}
\hline \multirow[b]{2}{*}{ Cultivar, treatment ${ }^{\mathrm{z}}$} & \multirow[b]{2}{*}{ Foliar insecticide treatment } & \multicolumn{2}{|c|}{ Stand $(\%)^{x}$} & \multicolumn{2}{|c|}{ Leafminer $(\%)^{\mathrm{y}}$} \\
\hline & & 2010 & 2011 & 2010 & 2011 \\
\hline \multicolumn{6}{|l|}{ B-45 } \\
\hline Untreated check & Untreated check & 76 & 53 & $77 \mathrm{a}$ & $97 \mathrm{a}$ \\
\hline Untreated & Scorpion & ND & 54 & ND & $91 \mathrm{~b}$ \\
\hline Poncho Beta & Untreated & 76 & 54 & $0 \mathrm{~b}$ & $0 \mathrm{c}$ \\
\hline Poncho Beta & Movento + Provado & 73 & 55 & $0 \mathrm{~b}$ & $1 \mathrm{c}$ \\
\hline NipsIt INSIDE & Untreated & 74 & 58 & $0 \mathrm{~b}$ & $0 \mathrm{c}$ \\
\hline Cruiser Force & Untreated & 81 & 54 & $0 \mathrm{~b}$ & $1 \mathrm{c}$ \\
\hline$P>F$ & $\ldots$ & 0.7732 & 0.4675 & $<0.0001$ & $<0.0001$ \\
\hline LSD & $\ldots$ & NS & NS & 2 & 6 \\
\hline \multicolumn{6}{|l|}{$\mathrm{C}-21$} \\
\hline Untreated check & Untreated check & 70 & $70 \mathrm{~b}$ & $65 \mathrm{a}$ & $84 \mathrm{a}$ \\
\hline Untreated & Scorpion & ND & $75 \mathrm{ab}$ & ND & $72 \mathrm{~b}$ \\
\hline Poncho Beta & Untreated & 59 & $81 \mathrm{a}$ & $0 \mathrm{~b}$ & $1 \mathrm{c}$ \\
\hline Poncho Beta & Movento + Provado & 63 & $77 \mathrm{ab}$ & $0 \mathrm{~b}$ & $1 \mathrm{c}$ \\
\hline NipsIt INSIDE & Untreated & 62 & $82 \mathrm{a}$ & $0 \mathrm{~b}$ & $0 \mathrm{c}$ \\
\hline Cruiser Force & Untreated & 66 & $80 \mathrm{a}$ & $0 \mathrm{~b}$ & $0 \mathrm{c}$ \\
\hline$P>F$ & $\ldots$ & 0.7331 & 0.0265 & $<0.0001$ & $<0.0001$ \\
\hline LSD & $\ldots$ & NS & 8 & 4 & 8 \\
\hline
\end{tabular}

${ }^{w}$ Means followed by the same letter did not differ based on Fisher's protected least significant difference (LSD) value, with $\alpha=0.05$. ND $=$ no data and NS $=$ not significant.

${ }^{x}$ Number of plants at the cotyledon growth stage (prior to thinning) were counted in a 10-ft of row and percent emergence determined.

y Percentage of plants infested with beet leafminer (Pegomya betae). Data analysis was also conducted with arcsine-transformed data but mean separation with the untransformed data was the same. Thus, the untransformed analysis is presented.

${ }^{\mathrm{z}}$ Insecticide seed treatments were Untreated check $=$ no seed or foliar insecticide; Untreated $=$ no insecticide treatment; Poncho Beta $=$ clothianidin at $60 \mathrm{~g}$ a.i. per 100,000 seeds $+\beta$-cyfluthrin at $8 \mathrm{~g}$ a.i. per 100,000 seeds; NipsIt INSIDE $=$ clothianidin at $60 \mathrm{~g}$ a.i. per 100,000 seeds; Cruiser Force $=$ thiamethoxam at $60 \mathrm{~g}$ a.i. per 100,000 seeds + tefluthrin at $8 \mathrm{~g}$ a.i. per 100,000 seeds. The foliar insecticide treatments were applied twice (in 2010 , on 16 June, 7 days prior to hopper release and repeated on 28 June; in 2011, on 21 June, 6 days prior to hopper release and repeated on 5 July): Movento + Provado = Movento $240 \mathrm{SC}$ (spirotetramat at $88 \mathrm{~g}$ a.i./ha) + Provado 1.6 F (imidacloprid at $52.8 \mathrm{~g}$ a.i./ha), and Scorpion 35SL (dinotefuran at $149 \mathrm{~g}$ a.i./ha). For more information on the coded cultivars B-45 and C-21, contact Betaseed Inc. and ACH Seeds, respectively. $P>F$ was the probability associated with the $F$ value. 
ences among treatments with B-45 $(P=0.4675)$ but, with $\mathrm{C}-21$, there were differences $(P=0.0265$; Table 2$)$. With $C-21$ in 2011 , there was a trend for plants with an insecticide seed treatment to exhibit higher stand counts than the untreated check. In 2011, B-45 had lower than normal percent stand but there were still enough plants to require thinning. There was no phytotoxicity associated with any of the insecticide treatments. The metconazole fungicide applied with the NipsIt INSIDE seed treatment did cause some leaf deformation (lollipop shaped leaves) at the two- to four-leaf growth stage but plants recovered and grew normally during later growth stages.

Leafminer. In 2010, leafminer incidence at the six- to eight-leaf growth stage (50 days after planting) was 65 to $77 \%$ in the untreated checks (Table 2). All seed treatments resulted in complete control and were significantly $(P<0.0001)$ different from the untreated check. In 2011, leafminer incidence at the six- to eight-leaf growth stage (48 days after planting) was 84 to $97 \%$ in the untreated seed checks (Table 2). All seed treatments resulted in complete or nearly compete (only $1 \%$ incidence) control and were significantly $(P<0.0001)$ different from the untreated check.

Curly top. The distribution of six viruliferous beet leafhoppers per plant led to severe uniform curly top epiphytotics during both years (Supplementary Figure S1; Table 3). DNA testing indicated that BSCTV and BCTV were present in all 12 plants tested (6 tested each year), while BMCTV was not detected. Across the four cultivar-year ratings for the untreated checks, curly top was 3.8 to 4.4 in mid-July, 5.5 to 7.3 in mid-August, and 6.6 to 8.1 in midSeptember (Table 3). Across all ratings, the insecticide treatments had significantly $(P=0.0003$ to $<0.0001)$ fewer curly top symptoms (41\% reduction for seed treatments and $33 \%$ for Scorpion) than the untreated check (Table 3). Although some significant differences did occur among insecticide treatments, they were not consistent across rating date and cultivar. Averaged over all seed treatments, there was a 44 and $39 \%$ reduction in curly top symptoms relative to the untreated checks on B-45 and C-21, respectively. The Movento + Provado foliar treatment combined with the Poncho Beta seed treatment did not increase curly top protection compared with Poncho Beta seed treatment. The Scorpion foliar treatment tested without a seed treatment performed similarly to the seed treatments for curly top control, although NipsIt INSIDE resulted in fewer symptoms with C-21.

Yield variables. Root yield with the insecticide treatments was increased $(P<0.0001)$ by 55 to $95 \%$ compared with the untreated check, depending on cultivar and year (Table 4). With root yield, although there were significant differences at times among insecticide treatments, they were not consistent across cultivar and year. For percent sucrose, the insecticide treatments were higher $(P=$ 0.0013 to $<0.0001)$ by 6.5 to $7.2 \%$ compared with the untreated check, except for B-45 in 2011, where differences were not observed (Table 4). With percent sucrose, although there were significant differences at times among insecticide treatments, they were not consistent across cultivar and year. For estimated recoverable sucrose, the insecticide treatments increased yield $(P<0.0001)$ by 58 to $96 \%$ compared with the untreated check, depending on cultivar and year (Table 4). With estimated recoverable sucrose, although there were significant differences at times among insecticide treatments, they were not consistent across cultivar and year.

\section{Discussion}

The neonicotinoid active ingredients (clothianidin or thiamethoxam) in the seed treatments (Poncho Beta, NipsIt INSIDE, and Cruiser Force) provided good control when plants were exposed to severe curly top pressure 50 to 55 days after planting. The foliar neonicotinoid insecticide Scorpion (a.i. dinotefuran) provided good control of severe curly top as well when applied 6 to 8 days prior to beet leafhopper release and again 5 to 8 days after release. These seed and foliar insecticide treatments increased root yield 55 to $95 \%$, sucrose content 6.5 to $7.2 \%$, and estimated recoverable sucrose 58 to $96 \%$ when compared with the untreated check. The foliar insecticides Movento and Provado when applied to plants with Poncho Beta-treated seed did not improve the control of curly top. In fact, the treatment with both foliar insecticides ranked worse in August and September disease ratings both years when compared with just using the seed treatment Poncho Beta. Thus, the seed treatments based on clothianidin or thiamethoxam appear very promising for limiting curly top through control of the beet

Table 3. Influence of insecticide seed and foliar treatments on curly top symptom severity using two conventional commercial sugar beet cultivars ('B-45' and 'C-21') during the 2010 and 2011 growing seasons near Kimberly, ID ${ }^{\mathrm{x}}$

\begin{tabular}{|c|c|c|c|c|c|c|c|}
\hline \multirow[b]{2}{*}{ Cultivar, treatment ${ }^{y}$} & \multirow[b]{2}{*}{ Foliar $^{\mathrm{z}}$} & \multicolumn{3}{|c|}{2010} & \multicolumn{3}{|c|}{2011} \\
\hline & & 16 July & 16 August & 16 September & 19 July & 16 August & 19 September \\
\hline \multicolumn{8}{|l|}{ B-45 } \\
\hline Untreated check & Untreated check & $4.4 \mathrm{a}$ & $7.3 \mathrm{a}$ & $7.8 \mathrm{a}$ & $3.8 \mathrm{a}$ & $6.5 \mathrm{a}$ & $8.1 \mathrm{a}$ \\
\hline Untreated & Scorpion & ND & ND & ND & $2.6 \mathrm{~b}$ & $4.1 \mathrm{~b}$ & $5.1 \mathrm{bc}$ \\
\hline Poncho Beta & Untreated & $2.5 \mathrm{~b}$ & $2.9 \mathrm{c}$ & $3.6 \mathrm{~b}$ & $2.3 \mathrm{~b}$ & $3.8 \mathrm{~b}$ & $4.7 \mathrm{bc}$ \\
\hline Poncho Beta & $\mathrm{M}+\mathrm{P}$ & $2.6 \mathrm{~b}$ & $4.0 \mathrm{~b}$ & $4.2 \mathrm{~b}$ & $2.4 \mathrm{~b}$ & $4.2 \mathrm{~b}$ & $5.9 \mathrm{~b}$ \\
\hline NipsIt INSIDE & Untreated & $2.8 \mathrm{~b}$ & $3.4 \mathrm{bc}$ & $3.8 \mathrm{~b}$ & $2.4 \mathrm{~b}$ & $3.7 \mathrm{~b}$ & $4.6 \mathrm{c}$ \\
\hline Cruiser Force & Untreated & $2.7 \mathrm{~b}$ & $3.6 \mathrm{~b}$ & $3.8 \mathrm{~b}$ & $2.2 \mathrm{~b}$ & $3.4 \mathrm{~b}$ & $4.4 \mathrm{c}$ \\
\hline$P>F$ & $\ldots$ & $<0.0001$ & $<0.0001$ & $<0.0001$ & 0.0003 & $<0.0001$ & $<0.0001$ \\
\hline LSD & $\ldots$ & 0.5 & 0.6 & 0.9 & 0.7 & 0.9 & 1.3 \\
\hline \multicolumn{8}{|l|}{ C-21 } \\
\hline Untreated check & Untreated check & $4.2 \mathrm{a}$ & $5.5 \mathrm{a}$ & $6.3 \mathrm{a}$ & $3.8 \mathrm{a}$ & $6.0 \mathrm{a}$ & $7.3 \mathrm{a}$ \\
\hline Untreated & Scorpion & ND & ND & ND & $3.0 \mathrm{~b}$ & $4.0 \mathrm{~b}$ & $4.5 \mathrm{~b}$ \\
\hline Poncho Beta & Untreated & $2.6 \mathrm{~b}$ & $2.9 \mathrm{c}$ & $3.7 \mathrm{bc}$ & $2.8 \mathrm{bc}$ & $3.6 \mathrm{bc}$ & $4.3 \mathrm{bc}$ \\
\hline Poncho Beta & $\mathrm{M}+\mathrm{P}$ & $2.5 \mathrm{~b}$ & $3.5 \mathrm{~b}$ & $3.8 \mathrm{bc}$ & $2.8 \mathrm{bc}$ & $4.0 \mathrm{~b}$ & $4.6 \mathrm{~b}$ \\
\hline NipsIt INSIDE & Untreated & $2.5 \mathrm{~b}$ & $3.2 \mathrm{bc}$ & $3.5 \mathrm{c}$ & $2.4 \mathrm{c}$ & $3.1 \mathrm{c}$ & $3.7 \mathrm{c}$ \\
\hline Cruiser Force & Untreated & $2.5 \mathrm{~b}$ & $3.5 \mathrm{~b}$ & $4.0 \mathrm{~b}$ & $2.6 \mathrm{bc}$ & $3.7 \mathrm{~b}$ & $4.4 \mathrm{~b}$ \\
\hline$P>F$ & $\ldots$ & $<0.0001$ & $<0.0001$ & $<0.0001$ & $<0.0001$ & $<0.0001$ & $<0.0001$ \\
\hline LSD & $\ldots$ & 0.4 & 0.5 & 0.5 & 0.5 & 0.6 & 0.7 \\
\hline
\end{tabular}

${ }^{\mathrm{x}}$ Curly top symptoms were evaluated on a scale of 0 to $9(0=$ healthy and $9=$ dead $)$ in a continuous manner. Means followed by the same letter did not differ based on Fisher's protected least significant difference (LSD) value, with $\alpha=0.05$. ND = no data.

${ }^{\mathrm{y}}$ Insecticide seed treatments were Untreated check $=$ no seed or foliar insecticide; Untreated $=$ no insecticide treatment; Poncho Beta $=$ clothianidin at $60 \mathrm{~g}$ a.i. per 100,000 seeds $+\beta$-cyfluthrin at $8 \mathrm{~g}$ a.i. per 100,000 seeds; NipsIt INSIDE $=$ clothianidin at $60 \mathrm{~g}$ a.i. per 100,000 seeds; Cruiser Force $=$ thiamethoxam at $60 \mathrm{~g}$ a.i. per 100,000 seeds + tefluthrin at $8 \mathrm{~g}$ a.i. per 100,000 seeds. The foliar insecticide treatments were applied twice (in 2010 , on 16 June, 7 days prior to hopper release and repeated on 28 June; in 2011, on 21 June, 6 days prior to hopper release and repeated on 5 July): Movento + Provado = Movento $240 \mathrm{SC}$ (spirotetramat at $88 \mathrm{~g}$ a.i./ha) + Provado $1.6 \mathrm{~F}$ (imidacloprid at $52.8 \mathrm{~g}$ a.i./ha), and Scorpion $35 \mathrm{SL}$ (dinotefuran at 149 g a.i./ha). For more information on the coded cultivars B-45 and C-21, contact Betaseed Inc. and ACH Seeds, respectively. $P>F$ was the probability associated with the $F$ value.

z Foliar insecticide treatment. 
leafhopper virus vector along with the additional benefit of early season beet leafminer control.

Neonicotinoid seed treatments had been evaluated previously on sugar beet and shown to control curly top (32), provide early season pest control $(30)$, and decrease losses in storage $(33,34)$. However, these seed treatments had not been tested under severe curly top pressure or at one point in time to help establish the length of efficacy. In 2005, the initial studies which established clothianidin as an effective control for curly top were conducted with natural infestations with low to moderate pressure (32). The commercial cultivar with low resistance, 'Phoenix R', had mean curly top ratings of 4.5 and 5.3 during September in the two studies (32). In the present study conducted with two commercial cultivars, B-45 and C-21, with low levels of resistance, the mean curly top ratings in September were 7.8 and 6.3, respectively, in 2010 and 8.1 and 7.3, respectively, in 2011. Thus, the curly top pressure generated with six viruliferous beet leafhoppers per plant was considerably higher than tested previously. Yet the control provided by both clothianidin and thiamethoxam was highly effective. The same relationship between studies can be established when comparing the increase in estimated recoverable sucrose. In the 2005 studies, estimated recoverable sucrose with Phoenix $\mathrm{R}$ was increased $13.8 \%$ with Poncho Beta compared with the untreated check (32). In the 2010 and 2011 studies, Poncho Beta-treated seed had a mean yield $76.8 \%$ higher than the untreated check. These data also suggest that the 2010 and 2011 studies were conducted under severe curly top pressure, particularly when compared with the 2005 studies. By exposing the plants to six viruliferous beet leafhoppers 50 and 55 days after planting, these data also establish that the length of efficacy for clothianidin and thiamethoxam is at least 50 days for control of the beet leafhopper.

The neonicotinoid seed treatments clothianidin and thiamethoxam provide for effective early season control of leafminer $(30,32)$. Although the leafminer infestation was quite high, it likely did not influence yields much when compared with the losses caused by curly top. In 2005, the leafminer infestation at Kimberly was $83.3 \%$ in the untreated checks, yet the losses at Nampa with no leafminer pressure were higher because there was more curly top pressure (32). In 2010 and 2011, the leafminer pressure was 71 and $90 \%$, respectively. Although the leafminer pressure was similar to that observed in 2005, yield losses in the 2010 and 2011 studies were considerably higher and likely due to the higher curly top pressure. Łuczak reported up to 30\% reduction in root yields from the leafminer P. hyoscyami (Panzer) in Europe (20). Losses in sugar beet associated with damage from the closely related $P$. betae may be significant but are poorly understood in the Idaho growing area and should be investigated without the overwhelming influence of curly top.

Foliar treatments for curly top control have been unsuccessful or only marginally successful when tested previously (37). The foliar insecticide treatments Movento and Provado, when tested in 2010 and 2011, appeared to have no influence on the control of curly top beyond that provided by the Poncho Beta seed treatment. When Movento and Provado were evaluated on plants without an insecticide seed treatment, they also appeared to have no influence on the control of curly top (data not shown). However, the Scorpion foliar spray was as effective as the neonicotinoid seed treatments for the control of curly top when applied less than a week before and after infestation by viruliferous beet leafhoppers. The Scorpion spray was only evaluated in 2011; therefore, this product will need further evaluation before it can be definitively stated that it helps to control curly top. An application of this product toward the end of the efficacy period for the insecticide seed treatments might prove to be beneficial for extending curly top control. However, one of the primary drawbacks to foliar insecticides is their nonselective nature, which leads to effects on non-target organisms.

Based on the success of Poncho Beta for curly top control, some sugar beet production areas now require a neonicotinoid seed treatment on all sugar beet seed. The only alternative on sugar beet to clothianidin (a.i. in Poncho) is thiamethoxam, which is a closely related neonicotinoid. If Scorpion (a.i. dinotefuran, also a neonicotinoid) is applied as a foliar treatment during the season, there is continual selection pressure for neonicotinoids. Resistance management then becomes a concern. Both clothianidin and thiameth-

Table 4. Influence of insecticide seed and foliar treatments on yield variables using two conventional commercial sugar beet cultivars ('B-45' and 'C-21') during the 2010 and 2011 growing seasons near Kimberly, ID ${ }^{\mathrm{w}}$

\begin{tabular}{|c|c|c|c|c|c|c|c|}
\hline \multirow[b]{2}{*}{ Cultivar, treatment ${ }^{\mathrm{y}}$} & \multirow[b]{2}{*}{ Foliar $^{\mathrm{z}}$} & \multicolumn{2}{|c|}{ Root yield (t/ha) } & \multicolumn{2}{|c|}{ Sucrose content (\%) } & \multicolumn{2}{|c|}{$\operatorname{ERS}(\mathbf{k g} / \mathbf{h a})^{x}$} \\
\hline & & 2010 & 2011 & 2010 & 2011 & 2010 & 2011 \\
\hline \multicolumn{8}{|l|}{ B-45 } \\
\hline Untreated check & Untreated check & $2.9 \mathrm{c}$ & $19.5 \mathrm{c}$ & $13.73 \mathrm{~b}$ & 15.14 & $324 c$ & $2,562 \mathrm{c}$ \\
\hline Untreated & Scorpion & ND & $60.4 \mathrm{ab}$ & ND & 15.07 & ND & $7,588 \mathrm{ab}$ \\
\hline Poncho Beta & Untreated & $70.0 \mathrm{a}$ & $59.8 \mathrm{ab}$ & $14.83 \mathrm{a}$ & 15.59 & $8,352 \mathrm{a}$ & $7,880 \mathrm{ab}$ \\
\hline Poncho Beta & $M+P$ & $63.3 \mathrm{ab}$ & $56.7 \mathrm{~b}$ & $14.71 \mathrm{a}$ & 15.10 & $7,425 a b$ & $7,136 \mathrm{~b}$ \\
\hline NipsIt INSIDE & Untreated & $65.5 \mathrm{ab}$ & $67.3 \mathrm{ab}$ & $14.80 \mathrm{a}$ & 15.57 & $7,691 \mathrm{ab}$ & $8,754 \mathrm{ab}$ \\
\hline Cruiser Force & Untreated & $57.6 \mathrm{~b}$ & $69.8 \mathrm{a}$ & $14.47 \mathrm{a}$ & 15.44 & $6,666 \mathrm{~b}$ & $9,079 \mathrm{a}$ \\
\hline$P>F$ & $\ldots$ & $<0.0001$ & $<0.0001$ & 0.0013 & 0.1224 & $<0.0001$ & $<0.0001$ \\
\hline LSD & $\ldots$ & 8.2 & 12.4 & 0.54 & NS & 1,153 & 1,764 \\
\hline \multicolumn{8}{|l|}{$\mathrm{C}-21$} \\
\hline Untreated check & Untreated check & $7.2 \mathrm{~b}$ & $29.2 \mathrm{c}$ & $14.14 \mathrm{~b}$ & $14.02 \mathrm{~d}$ & $852 \mathrm{~b}$ & $3,493 \mathrm{~d}$ \\
\hline Untreated & Scorpion & ND & $58.0 \mathrm{~b}$ & ND & $14.76 \mathrm{c}$ & ND & $7,096 \mathrm{c}$ \\
\hline Poncho Beta & Untreated & $62.9 \mathrm{a}$ & $63.2 \mathrm{~b}$ & $14.98 \mathrm{a}$ & $14.94 \mathrm{bc}$ & $7,428 \mathrm{a}$ & $7,805 \mathrm{bc}$ \\
\hline Poncho Beta & $M+P$ & $66.8 \mathrm{a}$ & $63.5 \mathrm{~b}$ & $15.24 \mathrm{a}$ & $15.21 \mathrm{ab}$ & 8,187 a & $8,031 \mathrm{bc}$ \\
\hline NipsIt INSIDE & Untreated & $63.8 \mathrm{a}$ & $77.2 \mathrm{a}$ & $15.12 \mathrm{a}$ & $15.44 \mathrm{a}$ & $7,703 \mathrm{a}$ & $9,949 \mathrm{a}$ \\
\hline Cruiser Force & Untreated & $61.2 \mathrm{a}$ & $65.5 \mathrm{~b}$ & $15.13 \mathrm{a}$ & $15.21 \mathrm{ab}$ & $7,388 \mathrm{a}$ & $8,346 \mathrm{~b}$ \\
\hline$P>F$ & $\ldots$ & $<0.0001$ & $<0.0001$ & 0.0003 & $<0.0001$ & $<0.0001$ & $<0.0001$ \\
\hline LSD & $\ldots$ & 7.4 & 8.0 & 0.47 & 0.36 & 949 & 1,015 \\
\hline
\end{tabular}

${ }^{\text {w}}$ Means followed by the same letter did not differ based on Fisher's protected least significant difference (LSD) value, with $\alpha=0.05$. ND $=$ no data and NS $=$ not significant.

${ }^{\mathrm{x}} \mathrm{ERS}=$ estimated recoverable sucrose.

${ }^{\mathrm{y}}$ Insecticide seed treatments were Untreated check $=$ no seed or foliar insecticide; Untreated $=$ no insecticide treatment; Poncho Beta $=$ clothianidin at $60 \mathrm{~g}$ a.i. per 100,000 seeds $+\beta$-cyfluthrin at $8 \mathrm{~g}$ a.i. per 100,000 seeds; NipsIt INSIDE $=$ clothianidin at $60 \mathrm{~g}$ a.i. per 100,000 seeds; Cruiser Force $=$ thiamethoxam at $60 \mathrm{~g}$ a.i. per 100,000 seeds + tefluthrin at $8 \mathrm{~g}$ a.i. per 100,000 seeds. The foliar insecticide treatments were applied twice (in 2010 , on 16 June, 7 days prior to hopper release and repeated on 28 June; in 2011, on 21 June, 6 days prior to hopper release and repeated on 5 July): Movento + Provado = Movento $240 \mathrm{SC}$ (spirotetramat at $88 \mathrm{~g}$ a.i./ha) + Provado $1.6 \mathrm{~F}$ (imidacloprid at $52.8 \mathrm{~g}$ a.i./ha), and Scorpion 35SL (dinotefuran at $149 \mathrm{~g}$ a.i./ha). For more information on the coded cultivars B-45 and C-21, contact Betaseed Inc. and ACH Seeds, respectively. $P>F$ was the probability associated with the $F$ value.

${ }^{\mathrm{z}}$ Foliar insecticide treatment. 
oxam are second-generation neonicotinoids (heterocycle of chlorinated thiazole) whereas dinotefuran is a third-generation neonicotinoid (heterocycle of tetrahydrofuran). In cotton aphids with resistance to imidacloprid, a first-generation neonicotinoid (heterocycle of chloropyridine), there was no obvious cross resistance to clothianidin, thiamethoxam, or dinotefuran (27). However, there was some cross resistance with other first-generation neonicotinoids (27). Some issues have arisen in the control of other pests; however, most reported cases of resistance have been relatively manageable or geographically localized, and most targeted insects have not shown resistance problems despite the widespread use of neonicotinoids $(1,11,13,17,24,25,28,36)$. Although resistance problems with neonicotinoids have been manageable, we need to remain vigilant about resistance to neonicotinoids. Therefore, although clothianidin and thiamethoxam are quite effective as seed treatments for the control of curly top, alternative chemistries, or at least a different generation of neonicotinoid, need to be established to aid in resistance management. To obtain the best control of curly top, the clothianidin and thiamethoxam seed treatments should be combined with the highest level of host resistance possible. Future research should focus on improving the level of host resistance in commercial cultivars and finding alternatives to the second-generation neonicotinoids.

\section{Acknowledgments}

These data support the objectives of the United States Department of Agriculture CRIS project 5368-21220-002-00D. We thank the Snake River Sugarbeet Growers and Beet Sugar Development Foundation for supporting our research work and T. Brown, J. Reed, and D. Kenney for their technical support.

\section{Literature Cited}

1. Alyokhin, A., Dively, G., Patterson, M., Castaldo, C., Rogers, D., Mahoney, M., and Wollam, J. 2007. Resistance and cross-resistance to imidacloprid and thiamethoxam in the Colorado potato beetle Leptinotarsa decemlineata. Pest Manage. Sci. 63:32-41.

2. Bartens, A., 2005. International Commission for Uniform Methods of Sugar Analysis Methods Book 2005. Dr. Albert Bartens KG, Berlin.

3. Bennett, C. W. 1971. The curly top disease of sugarbeet and other pests. Monogr. No. 7. American Phytopathological Society Press, St. Paul, MN.

4. Blickenstaff, C. C., and Traveller, D. 1979. Factors affecting curly top damage to sugarbeets and beans in southern Idaho, 1919-77. Science and Education Administration, Agricultural Reviews and Manuals, Western Ser. No. 8. USDA-ARS, Oakland, CA.

5. Briddon, R. W., Heydarnejad, J., Khosrowfar, F., Massumi, H., Martin, D. P., and Varsani, A. 2010. Turnip curly top virus, a highly divergent geminivirus infecting turnip in Iran. Virus Res. 152:169-175.

6. Camp, S., Foote, P., Strausbaugh, C. A., and Gillen, A. M., 2005. Evaluation of commercial sugar beet hybrids for resistance to beet curly top in Canyon County, ID, 2004. Biol. Cult. Tests Control Plant Dis. 20:FC023.

7. Chen, L.-F., Vivoda, E., and Gilbertson, R. L. 2011. Genetic diversity in curtoviruses: a highly divergent strain of Beet mild curly top virus associated with an outbreak of curly top disease in pepper in Mexico. Arch. Virol. 156:547-555

8. Creamer, R., Luque-Williams, M., and Howo, M. 1996. Epidemiology and incidence of beet curly top geminivirus in naturally infected weed hosts. Plant Dis. 80:533-535.

9. Crop Production Statistics by State. 2001 to 2010. United States Department of Agriculture-National Agricultural Statistics Service, Washington, DC. www.nass.usda.gov

10. Duffus, J. E., and Skoyen, I. O. 1977. Relationship of age of plants and resistance to a severe isolate of the beet curly top virus. Phytopathology 67:151-154.

11. Foster, S. P., Cox, D., Oliphant, L., Mitchinson, S., and Denholm, I. 2008. Correlated responses to neonicotinoid insecticides in clones of the peachpotato aphid, Myzus persicae (Hemiptera: Aphididae). Pest Manage. Sci. 64:1111-1114.

12. Gillen, A. M., Strausbaugh, C. A., and Tindall, K. V. 2008. Evaluation of Beta corolliflora for resistance to curly top in Idaho. J. Sugar Beet Res. 45:99-118.

13. Gorman, K., Liu, Z., Denholm, I., Brüggen, K.-U., and Nauen, R. 2008. Neonicotinoid resistance in rice brown planthopper, Nilaparvata lugens. Pest Manage. Sci. 64:1122-1125.

14. Hernandez, C., and Brown, J. K. 2010. First report of a new Curtovirus species, Spinach severe curly top virus, in commercial spinach plants (Spinacia oleracea) from south-central Arizona. Plant Dis. 94:917.

15. Heydarnejad, J., Abhari, E. H., Yazdi, H. R. B., and Massumi, H. 2007. Curly top of cultivated plants and weeds and report of a unique Curtovirus from Iran. J. Phytopathol. 155:321-325.

16. Hudson, A., Richman, D. B., Escobar, I., and Creamer, R. 2010. Comparison of the feeding behavior and genetics of beet leafhopper, Circulifer tenellus, populations form California and New Mexico. Southwest. Entomol. 35:241-250.

17. Jeschke, P., and Nauen, R., 2008. Neonicotinoids-from zero to hero in insecticide chemistry. Pest Manage. Sci. 64:1084-1098.

18. Kaffka, S. R., Wintermantel, W. M., and Lewellen, R. T. 2002. Comparisons of soil and seed applied systemic insecticides to control Beet curly top virus in the San Joaquin Valley. J. Sugar Beet Res. 39:59-74.

19. Lam, N., Creamer, R., Rascon, J., and Belfon, R. 2009. Characterization of a new Curtovirus, Pepper yellow dwarf virus, from chile pepper and distribution in weed hosts in New Mexico. Arch. Virol. 154:429-436.

20. Luczak, I. 1987. Harmfulness of spinach leaf miner (Pegomyia hyoscyami Panz.) on various sugar beet cultivars. Part I. Leaf miner's effect on yield of roots and leaves. Biul. Inst. Hodowli I Aklimatyzacji Roślin 163:192-205.

21. Malm, N. R., and Finkner, R. E. 1968. The use of systemic insecticides to reduce the incidence of curly top virus disease in sugarbeets. J. Am. Soc. Sugar Beet Technol. 15:246-254.

22. Mumford, D. L. 1974. Procedure for inducing curly top epidemics in field plots. J. Am. Soc. Sugar Beet Technol. 18:20-23.

23. Mumford, D. L., and Griffin, G. D. 1973. Evaluation of systemic pesticides in controlling sugarbeet leafhopper. J. Am. Soc. Sugar Beet Technol. 17:354-357.

24. Nauen, R., and Denholm, I. 2005. Resistance of insect pests to neonicotinoid insecticides: current status and future prospects. Arch. Insect Biochem. Physiol. 58:200-215.

25. Nauen, R., Denholm, I., Dennehy, T., and Nichols, R., 2008. News from the front line: reports from the global workshop on the stewardship on neonicotinoid insecticides, Honolulu, Hawaii, 5-6 June 2008. Pest Manage. Sci. 64:1082-1083.

26. Ritenour, G., Hills, F. J., and Lange, W. H. 1970. Effect of planting date and vector control on the suppression of curly top and yellows in sugarbeet. J. Am. Soc. Sugar Beet Technol. 16:78-84

27. Shi, X., Jiang, L., Wang, H., Qiao, K., Wang, D., and Wang, K. 2011. Toxicities and sublethal effects of seven neonicotinoid insecticides on survival, growth and reproduction of imidacloprid-resistant cotton aphid, Aphis gossypii. Pest Manage. Sci. 67:1528-1533.

28. Slater, R., Paul, V. L., Andrews, M., Garbay, M., and Camblin, P. 2011. Identifying the presence of neonicotinoid-resistant peach-potato aphid (Myzus persicae) in the peach-growing regions of southern France and northern Spain. Pest Manage. Sci. Online publication. doi:10.1002/ps.2307.

29. Stenger, D. C., and McMahon, C. L. 1997. Genotypic diversity of beet curly top virus populations in the western United States. Phytopathology 87:737744.

30. Strausbaugh, C. A., Eujayl, I. A., and Foote, P. 2010. Seed treatments for the control of insects and diseases in sugarbeet. J. Sugar Beet Res. 47:105-125.

31. Strausbaugh, C. A., Gillen, A. M., Camp, S., Shock, C. C., Eldredge, E. P., and Gallian, J. J. 2007. Relationship of beet curly top foliar ratings to sugar beet yield. Plant Dis. 91:1459-1463.

32. Strausbaugh, C. A., Gillen, A. M., Gallian, J. J., Camp, S., and Stander, J. R. 2006. Influence of host resistance and insecticide seed treatments on curly top in sugar beets. Plant Dis. 90:1539-1544.

33. Strausbaugh, C. A., Rearick, E., and Camp, S. 2008. Influence of curly top and Poncho Beta on storability of sugarbeet. J. Sugar Beet Res. 45:31-47.

34. Strausbaugh, C. A., Rearick, E., Eujayl, I. A., and Foote, P. 2010. Effect of insecticide seed treatments on sugarbeet storability. J. Sugar Beet Res. 47:65-88.

35. Strausbaugh, C. A., Wintermantel, W. M., Gillen, A. M., and Eujayl, I. A. 2008. Curly top survey in the western United States. Phytopathology 98:1212-1217.

36. Wang, Y., Chen, J., Zhu, Y. C., Ma, C., Huang, Y., and Shen, J. 2008. Susceptibility to neonicotinoids and risk of resistance development in the brown planthopper, Nilaparvata lugens (Stål) (Homoptera: Delphacidae). Pest Manage. Sci. 64:1278-1284.

37. Wang, H., Gurusinghe, P. de A., and Falk, B. W. 1999. Systemic insecticides and plant age affect beet curly top virus transmission to selected host plants. Plant Dis. 83:351-355.

38. Wintermantel, W. M., and Kaffka, S. 2006. Sugar beet performance with curly top is related to virus accumulation and age at infection. Plant Dis. 90:657-662.

39. Yazdi, H. R. B., Heydarnejad, J., and Massumi, H. 2008. Genome characterization and genetic diversity of beet curly top Iran virus: A geminivirus with a novel nonanucleotide. Virus Genes 36:539-545. 